This article was downloaded by: [University of Bath] On: 02 March 2015, At: 06: 45

Publisher: Routledge

Informa Ltd Registered in England and Wales Registered Number: 1072954 Registered office: Mortimer House, 37-41 Mortimer Street, London W1T 3J H, UK

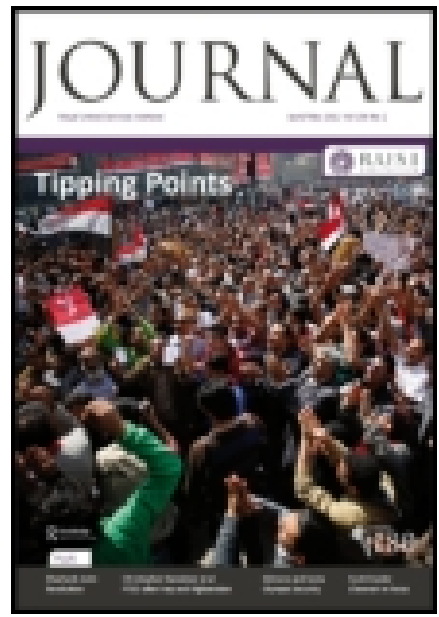

Royal United Services Institution. J ournal

Publication details, including instructions for authors and subscription information: http:// www. tandfonline.com/ loi/rusi19

\title{
On Circular Ironclads
}

E. J. Reed Esq. C. B., M.P. Published online: 11 Sep 2009.

To cite this article: E. J. Reed Esq. C. B., M. P. (1876) On Circular Ironclads, Royal United Services Institution. J ournal, 20:85, 85-109, DOI: 10.1080/03071847609427101

To link to this article: http://

dx. doi. org/ 10.1080/03071847609427101

\section{PLEASE SCROLL DOWN FOR ARTICLE}

Taylor \& Francis makes every effort to ensure the accuracy of all the information (the "Content") contained in the publications on our platform. However, Taylor \& Francis, our agents, and our licensors make no representations or warranties whatsoever as to the accuracy, completeness, or suitability for any purpose of the Content. Any opinions and views expressed in this publication are the opinions and views of the authors, and are not the views of or endorsed by Taylor \& Francis. The accuracy of the Content 
should not be relied upon and should be independently verified with primary sources of information. Taylor and Francis shall not be liable for any losses, actions, claims, proceedings, demands, costs, expenses, damages, and other liabilities whatsoever or howsoever caused arising directly or indirectly in connection with, in relation to or arising out of the use of the Content.

This article may be used for research, teaching, and private study purposes. Any substantial or systematic reproduction, redistribution, reselling, loan, sub-licensing, systematic supply, or distribution in any form to anyone is expressly forbidden. Terms \& Conditions of access and use can be found at http://www.tandfonline.com/page/termsand-conditions 


\title{
LECTỦRE.
}

Friday, February 4th, 1876.

ADMrRai Sir HASTINGS R. YELLERTON, G.C.B., in the Chair.

\section{ON CIRCULAR IRONCLADS.}

\author{
Bז E. J. Reed, Esq., C.B., M.P.
}

I nOPE I may be excused for saying at the commencement of this paper that I have undertaken to write it at the request of the Council of this Institution, and not from any desire on my part to add at present to the public statements which $T$ have already mado concerning circular ironclads. Nevertheless, as the desire of the Council was based, I presume, upon the remarks apon this class of ressel, made in certain letters which I wrote from Russia last autumn, and as those remarks hare since been subjected-as I at the time feared they would be-to much misconception and much misrepresentation, I ought to feel, and do feel, grateful to the Council for having roluntarily afforded me this opportunity of stating more fully my views upon the subject.

Whaterer may be the merits or demerits of circular ironclads, it will be admitted by all present that their construction by the Russian Government for service in the south is a noteworthy fact, and that I should havo been wanting to myself, and perhaps to others, if $I$ had failed to arail myself of a rery farourable opportunity for inspecting these ressels and witnessing their performance at sea. That was the object of my recent risit to Russia, and the opinions which I formed of them were stated with considerable care in my letters to The Times. On the present occasion, I propose to discuss the question in an essentially different manner.

But let us at the outset get as clearly as possible into our minds an idea of what the circular ironclads of Russia are. In the first place they are circular only in one sense, i.e., their horizontal sections only are circular, or, in other words, they hare circular water lines. The only departure from a circle is a small extension or protuberance at the stern for the purpose of facilitating the arrangement and working of the rudder and stecring apparatus. It follows as a consequence, from the circular form of water line, that all the radial sections are alike. In the earlier proposals for circular ironclads, for example, such as those suggested by the late Mr. John Elder, ${ }^{1}$ and, if $\mathrm{I}$ remember rightly, by Sir Samuel Baker, the midship section of the ressel was an arc of a circle, and therefore, in order to get the requisite displacement, the depth or draught of water of the vessel had to bear a considerable proportion to the diameter at the water line, and this involred, in the case of ressels carrying heary armour, a dranght of water which would be too great for hearily-armoured coast defence vessels. The

I Sce Journal of the Institution, No. 52, Vol. rii, page 529, et seq. 
circular ironclads of Russia, or.Popoffkas, hare quite a different form of section, the bottom of the ressel being an extended plane surface, which is connected with the edge of the deck by a quadrant of a small circle. With this form of section great displacement is obtained on moderate draught of water. The deck of the circular ship is formed in section with such curratare as to give in a ship of 100 feet in diameter a round-up of about four fect. There are two Popoffkas alrendy built, named respectively the "Novgorod," Fig. 1, and the "Admiral Popaff," Fig. 2, of which the following are the dimensions and other particulars:-

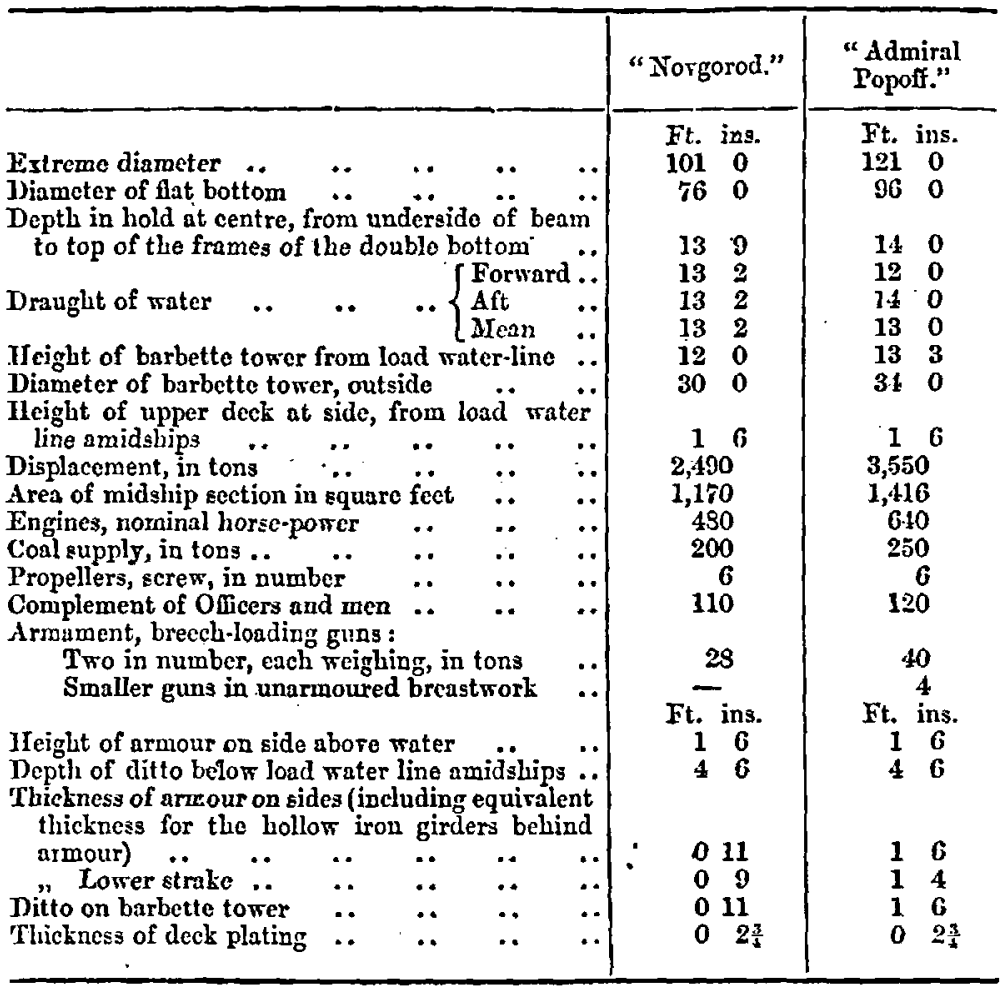

It is but fair to the distinguished designer of these ressels, carefully to bear in mind that, in so far as the "Norgorod" and "Admiral Popoff" are concerned, they have been designed and built purely for service in shallow waters and near the land. You will all remember that during our great war with Russia in the Black Sea and Crimea, the coasts of the Sea of Azof vere raraged by the small and weak unarmoured ressels of our Navj, and that the defences of Kinburm were destroyed by English and French floating batteries which were protected by armour of only four inches thick. The impunity with 
Which we thas assailed the Russian coasts on the Azof and at the mouth of the Dnieper, suggested to the Russian Government the necessity of providing sufficiently-armoured floating defences for protection in the future; and whatever we may think of the suitability of the circular vessels for sen-going purposes, we shall all, I presume, agree that in the two ships above described, the Russian Government bas put itself into possession of light draught vessels of unexampled power, both offensive and defensive, as compared with the armoured vessels of equally light draught belonging to any and every other country. In this country it must be acknowledged that the problem of producing armour-clad vessels, subject only to the conditions of 13 feet dranght, 8 knots speed, thick armour, and heavy guns, has never been put by the administrators of the Navy to the constructors of the Navy. During the seven years that I filled the office of Chief Constructor of the Nary, the only light draught armoured ressels that I was called upon to design were certain very small vessels, the breadth or beam of which was limited to a comparatively small amount, to make them fit for service on the inland waters of North America, and a vessel or two for colonial use, under conditions imposed by colonial requirements. The administrators of the Navy hare usually considered-and for my part I have concurred with them-that the necessity for ships capable of performing service abrond is, in our Nary, so much more urgent than that for purely coast-defence ressels, that sea-going qualitics at least sufficient to make the ships safe at sea, have been for the most part of primary importance. It is quite open to me, therefore, and to erery one, to admit the great qualities of these circular ships, without in any way depreciating our own work as English constructors; and it would be well if those persons who have endearoured to find - in such praise as I have accorded to the circular ships, a condemnation of English ressels, would bear this very important consideration carefully in mind.

With reference to the performance of these circular coast defence ironclads of Russia, I cannot, I. fear, do much more than simply repeat what I wrote to The Times on the subject. As regards speed, only a low speed was required for the object in view, and with engines of 480 nominal borse-power, manufactured in Rnssia, a speed of $8 \frac{1}{2}$ knots has been obtained in the "Norgorod." She has steamed long distances at an arerage speed of $7 \frac{1}{2}$ knots, and when $I$ was on board we easily averaged over $6 \frac{1}{2}$ knots, although the machinery was out of order, and much steam was wasted. I cannot gire the indi. cated power dereloped, for we had not on board the means of determining it; 2,270 indicated horse-power has subsequently been given to me as the fullest power developed in this vessel. If wo consider only the displacement of the vessel, this will no doubt be thought, a large power to employ in obtaining a speed of only about 8 knots; but displacement only is a very delusive standard to judge by; the true standard is the offensive and defensive powrer of the ressel, and I do not believe any" other ressel exists, equal to the "Norgorod" in these respects, in which a like speed is obtained with like power. Our 
colonial defence vessels of the "Cerberus" class, of my own design, conie nearest to the "Norgorod" of any vessels I know, and they certainly steam a knot faster with two-thirds of the power. They also carry 72 tons weight of guns against tho "Novgorod's" 56 tons, although this discrepancy is partly compensated in the "Novgorod" by a larger coal supply, after allowing for the increase of fuel required by the larger power. But the "Cerberus" draws 2 fect more water than the "Norgorod," and her defensive powers are not nearly so great as the "Novgorod's," owing to so much of the armour being of less thickness.

With regard to the bchaviour of the "Novgorod" at sea, I must say that it was remarkably good. We left tho roadstead of 'Theodosia when a night's gale of nind, blowing across the full extent of the Black Sea from the S.IF., had raised a considerable sea, and when a strong brecze was still blowing. The motions of the resscl, both rolling and pitching, were very unoderate, nerer, according to the best measures I could take, reaching as much as 7 degrees. The vertical rise and fall of the centre of the ressel scemed absolately nil, and the guns could bare been fred at any time with excellent aim, and in any direction whaterer, cxcepting only in the line of tho funnels, and of the stecring deck-Louse aft. I, who seldom escape some sensalion of sickness at sea, felt perfectly at home and com. fortable in the "Novgorod" throughout the rogage.

It was impossible to avoid observing how much more efficiently a ressel of this form is protected by her armour than is a ressel of the usual forn. In ordinary ships; as sou well hnow, great exposure results from pitching, from rolling, and from the alternation of ware hollows and crests along the ships' sides. No one who has anxionsly considered the circumstances of ironclads in an engagement at sea can donbt, I think, that with armonr stopping as it has hitherto stopped some fire, six, or at the most seven feet under the water-and at much less than these depths at the bow and stern-wuch of the bottom of the ship below armour is in a sca-way exposed occasionally and repeatedly to the firc of the enemies guns. From the first day of my connection with ironclad ships I felt the force of this consideration, and fondly hoped to carry tho armour continually lower npon the sides of our ironclad frigates as we made progress in other ways. Bat in a service like the Royal Nary, and where the constructor is bnt a humble scrrant of the Admiralty in so many things, I nerer was able, I think, to get besond the depth to which the armour of the "Bellerophon" and the "Hercules" was carried, and undoubtedly" the length oven of our shortest ships occasions so great a demand for armour that it lias not been possible, consistently with other conditions which were thought more important, to carry the armour lower than it was carricd in the vessels just named. For you will sec at a glanco that in the case of all vessels where the belt extends from bow to stern an increased depth of armour if anifornly carried means increased depth and weight over the whole length of the vessel. The result is, as I say, that at sea the armour-belt is frequently abandoned by the wares, and the botton below armour becones thus subjected to occasional 
and eren frequent exposure. $Y$ know that this consideration has weighed with many naval officers, and it was greatly urged in the case of the "Devastation" by tro Oificers with whom I do not at all times agree, riz.; Admirals Elliot and Ryder; and some derices wero resorted to in that ship and in similar ressels with the sanction of the Admiralty for compensating in some degree for the exposure of the ship at the ends when in a sea-was. It is no doubt true that the largest part of this exposure is at the ends, and is occasioned by the ship pitching, and by the hollowing of the sea between the wares. But rolling also is, of course, a great cause of exposure likewise, and 1 have considered that in securing great steadiness for modern ironclads in comparison with the early ones, by diminishing the stability (even to the extent of occasionally incurring undue crankness, afterwards compensated by ballast), we hare materially mitigated the danger of this kind of exposure. Bnt after all is done that can be done to check rolling, ships will roll at times, and may have to engare ensmies when rolling; and if it be true that the circular form of ressel involves less exposure of the hull below water than the ordinary form, there is in that fact a great and valuable element of increased safety (see Figs. 3. 4 and 5). As regards pitching it will be readily admitted, I presume, that ships which are no longer than they are broad, will at the bow and stern be in all probability very much less subjected to exposure of the kind we hare considered than ships of the ordinary form. In both respects, therefore, and on the whole, we may confidently expect that circular ships if approximately like the "Norgorod," will be found to expose the bottom of the vessel below armour very much less than ordinary ressels. Certainly the tendency to roll in the Black Sea, when the waves were of ample size to roll an ordinary ressel of her displacement, seemed to me to be singularly small; and as the circular form wherever adopted would no donbt be accompanied, as in the "Novgorod," by low freeboard for at least a considerable part of the vessel's length, all circular ressels will probably always be found to possess great advantages in these respects.

Presuming that all circular armour-elads are to resemble the "Norgorod," we may confidently predict for them a sccond vers important ad. vantage in point of defence. I allude to the fact that in the "Norgorod" and "Admiral Popoff" the armour is of uniform depth and uniform thickness at equal depths throughont the whole cxtent of the vessel's circumference. Now, in ressels of the ordinary form and proportions there is, and I am afraid always will be, a very grare deficiency in this respect. I believe I may say that erery ironclad frigate in existence is characterised by the fact that the armour is grently reduced in thickness as we pass from the midship portion towards the ends; and in some ships the reduction towards and at the ends is so great that the armour there is little more than nominal. We have been driven, by the length of the ship, to the use of tapering beltstapering, not only as regards breadth, but much more as regards thickness. Of course, this subject will bear looking at from the other side, and it may be said, with truth, that it has been most wise to give to the engine and boiler spaces and to the magazines a greater measure 
of protection than could be allowed to the ends of the ressel, the con. tents of which were of less vital moment. Still, looking to all the contingencies and risks of a naral engagement, I think every man who takes an ironclad ship into action would be glad to know that his armour tapered neither in breadth nor in thickness, and that a shot or shell fired squarely at him, whererer it might strike, would be equally resisted by his armoured defence. Now, when at sen in the "Norgorod" I felt strongly that this object is attained in her, and I think the simplicity and efficiency of the defensive armour of such a vessel will commend itself strongly to most practical naval Officers.

Those who have thought much of the construction of ironelad ship will have observed that hitherto the decks hare been subject to com. parative weakness, and that, but for the great comparative height of freeboard which ordinary ships possess, the decks must of necessity have been made a great deal stronger still. Of course, deck attack does not play, and probably never will play, a ver'y important part in naval actions at sea, for obvious reasons; bat, oren at sea, there are times when weakness of the deck might prove rery serious, and when. ever ironclad ships are required to attack or to def $y$ land fortresses, thes are liable to considerable deck attack from elerated guns. I think I am right in saying that, when a year or two since Admiral. Sir Hastings Yelverton was called upon to take by force two Spanistr frigates from the harbour of Carthagena, he had to perform that service with the knowledge that there were guns of $12 \frac{1}{2}$ tons sitnated in elerated batteries commanding his decks, and the risk of having to. withstand the fire of these guns, as well as of manj other powerful ones situated both ashore and afloat, had to be encountered on that occasion -an occasion which, in my hamble opinion, is deservedly considered to hare elicited from the gallant Officer whom I have named a display of coolness, courage, and determination which effectually proved that we may, with confidence, look in the future, as in the past, to our naval Officers for the full possession of these high qualities. Now, as against deck attack, the "Norgorod" seems rery fairly defended, after due allowance is made for the lowness and the upward slope of the deck. In so far as I hare in restigated the subject, I am also led to beliere that on the whole, and speaking generally, the circular ship would hare a decided advantage over others, in lending itself to complete armour protection, including that of the deck.

It will be seen from the foregoing that I am strongly disposed to credit circular ressels with great advantages as regards their defensire capabilities against the fire of guns. They possess further advantages, in my opinion, in the facility they afford for protection against the attack of torpedoes. I confess myself much astonished when I found that a gentleman writing to The Times declared that this form of ressel was more exposed to the attack of torpedoes than the ordinary form. I cannot see that this is true, even in case of the attack of fixed torpedoes in harbour entrances, or other life places, because the ares of the bottom of a circular ship is much smaller than the aren of the bottom of an ordinary ship, eren when we make allowances for the rise of the bottom of an ordinary ship as the sides and ends are 
approached, as compared with the flatness of the bottom of a circular ressel. In making a comparison of this kind we must adopt some tandard; I think the standard should be equal power to carry a given weight of battery armour and of protected gans in the ressels compared. Let us, then, take the case of two vessels about equal in this respect, and compare them by simply taking the areas of the load water section in each case. The "Glatton" and "Novgorod" are sufficiently near each other for our purpose, and we find that, while the area of the "Glatton's" water section is about 11,300 square feet, that of the "Novgorod" is about 8,000 square feet, thus showing a difference of 3,300 square feet, or, in other words, tho "Glatton's" area of water section is 41 per cent. greater than that of the circular ship. After making due allowance for the greater flatness of the "Novgorod's" bottom, she would still possess the advantage.

But if we pass from the case of ground or anchored torpedoes to the case of moving torpedoes, whether of the Harrey or the Whitehead types, it will be obrious that the circular ressel has much the advantage of the other, as regards liability to be struck. I think we may say that as such attacks will usually be directed to the broadside of the vessel, and will have for their object the destruction of the engine or boiler-room compartments, the relative exposures of the ressels will be approximately as are the areas of their longitudinal sections. Now, taking the two ressels just compared, we find the area of the "Glatton's" longitudinal vertical section, when at the ordinary designed load-draught, is 4,579 square feet, and at the fighting draught, 4,820 square fect, while that of the "Norgorod," at load draught, is about 1,170 square feet. Thus showing a proportion of about 4 to 1 in farour of the circnlar ship. Without dwelling longer upon the point, I must express $m y$ opinion that the advantage is greatly with the circular ressel as regards the chances of escaping the blow of the horizontal torpedo.

Bat the advantage of the circular vessel does not end here. With such a ressel it is obriously practicable to concentrate your steam power and your magazimes at and near the centre of the ship sufficiently to leave around them all a clear space many feet in width, which may be divided and sub-divided into rery many compartments so as to limit the extent of the injury when struck by a torpedo, to a degree that is not pussible with a long and narrow vessel (see Fig. 6). If Admiral Popoff's system of largely multiplying the propelling engines and screw propellers be adopted, we mas say more, for we may isolate each set of engines and boilers from the neighbouring set, and thus largely increase the chiances of preserving both the flotation and the propelling power after a torpedo blow had been struck. While on this point, I may admit that I consider for sea-going purposes the arrangement of the screw-propellers, and of the form of the ressel aft, would require to be modified somewhat from the arrangements and form of the "Popoffkas," in order to prevent the screws from protruding largely bejond the circumference of the ressel. As the "Novgorod" and the "Admiral Popoff" are to fight from shallow waters, the projection of their screw propellers is of but little moment, 
but in a sea-going ship it would not do to allow tho screws so to project that an enemy, by simply steaming past the stern in contact with it, would destroy or injure several of the propellers at once. There will be no difficulty, however, in making the necessury modifications, so that I need not here dwell apon the point. I may conclude my remarks on the defensive powers of circular ressels, by stating that $I$. am nnable to see how ressels of the usual form, can, by possibility, be made às secure as circular vessels from the blows of torpedoes and rams, and from the destructive effects of such blows.

It has been confidently stated that circular ships cannot bo efficiently steered. That they answer their helm with promptness and certainty is to me, after my experiences in the "Novgorod," absolutely certain. But, in point of fact, the objection is really based on the circumstance, that while in a long ship, when she is turning round under her helm, her length comes athwart her course and takes the momentum ont of her; a round ship, as she turns, has no such increased surface to oppose, and will therefore lose momentum less rapidly. This is no doubt perfectly true, but surely it is a matter of extremely small importance, and one entirely unworthy of consideration as a substantial objection to the employment of eircular ressels. In erery ship the steam powerwhich gires onward momentum to her, is always at hand to take it out of her by the reversal of the engines. This is therefore, merely at question of manæuvring, which our naval Officers are fnlly capable of solving.

You will expect me to say a few words about the low freeboard of these ressels. In ships of ordinary form and proportion there are many objections to low freeboard, bat the chief of these is reduced more and more as the length of the ship is diminished and the breadth increased, and they become of comparatively small importance in circular ships, in which the length is of course very short and the breadth rery great. I will here adrert only to two of the more serious objections to low freeboard ships of usual form : they would be deficient of stability, and the margin of surplus buosancy which they would possess would be too small for purposes of safety. A collision, or an accident much less serious than a collision, would suffice to send them quickly to the bottom. Mlore than one of the American "Monitors" were, if I remember rightly, sunk from the mere accident of a bateh in the deck being left open. But with the eircular form of slip, and with a greatly rounded deck like the decks of Admiral Popoll's ressels, both these objections are very materially diminished. In fact it is quite possible in a circular ship to adopt a rerg low freeboard and jet to have, with a well rounded deck, ample security for all purposes, and good surplus buoyancy likewise. For example suppose We take a circular ship of 150 feet in diameter and 12 fect draught, and therefore with a displacement of about 6,000 tons. With 2 feet 6 inches freebarrd, and a good round up of the deck, wo can have a surplus buoyancy of 3,000 tons. A ship 280 feet long and 54 broad, with about the same displacement $(6,000$ tons) would hare surplus bnojancy of about 300 or 320 tons per foot, and therefore, with the ordinary round up of deck, would require a freeboard of aboti 
9 fect to bring her surplus buoyancy up to an equality with that of the circular vessel with $2 \frac{1}{2}$ feet of freeboard. It is hardly necessary to remark upon the relative stabilities of two such vessels, because in cither case it would be ample for all the uses to which the circalar ship could be put. You will observe, therefore, that the circular form sweeps away some of the grarest objections to low freeboard. IVith reference to the sen flooding the low upper deck, much less of this takes place than would ordinarily be expected, and I am inclined to beliere that the trials of large circular ironclads, even in channel or Atlantic waves, would develop rery anexpected and satisfactory features.

In this connection I ought, nevertheless, to make it quite clear that the "Novgorod," and "Admiral Popoff," hare, like the "Devastation," rers extensive nnarmonred houses erected abore the, armoured dech. The chief of these is a spacious forecastle, which of course adds greatly to the buoyancy forward when the sea rises there upon the ressel, and I do not think eren circular ressels of very low freeboard could be steamed against a heary head sea without such a forecastle, moro especially, as wo shall see hereafter, when driven at a high speed. The forecastle, and other deckhouses, add very greatly to the accommo. dation and comfort of a circular ironclad.

In coming now to consider more generally the qualities of circular ressels, and especially of fast sca-going ressels, I think it right to sas most distinctly that the great value which I attach to Admiral Popoff's labours in this connection, springs from the stimulas thes exert in farour of reduced length and increased breadth in ironclads. The circular ships exhibit the limit of reduced length and increased breadth, and it is in this aspect that I wish to discuss the subject. I do not profess to be able to discuss it at all exhanstively ; my investigations have not gone nearly far enough for this, and it is upon investigation only that strong opinions in such a matter as this should be based. To say that circular ships can, or eren to suggest that thes possibly may, have bigl speed giren to them is a startling thing, for we all know that the resistance of such a form of ship must be very great indeed. We all know that grent steam-power must be needed to orercome that resistance. Still, having come to plate our ships with very thick armour, and to carry tremendously hoary concentrated armaments, we have now to ask whether the adoption of ordinary forms and proportions does not entail upon us greater disadrantages than an increase of steam power? In order to place the subject into due rela. tion to the broad question of ironclad construction, I have to ask you to look at it from this new point of riew: Hitherto the problem has been, how best to armour-plate ships? The problem to which I now invite your attention is, how best to adapt armour-plated fortresses for being sent to sea, and steaming there at sufficient speed?

This aspect of the subject is for all practical purpeses a jew one, and one which tho progress of erents has first made possible and then forced upon us. No doubt many persons-msself among the number - years ago conccived forms of floating fortresses capable of being sent to sea. But in a country like this there are many checks to rapid 
progress, and in dealing with a great service like the Nary it is unavoidable that improvement should-.

\section{"Slowly broaden down \\ From precedent to precedent."}

It was most natural, and on the whole I think most proper, that when the use of shell guns drove the Navy to the use of shell-proof armour, the application of such armour to something like existing ships was first resorted to. It must be remembered that steam itself was only introduced into the Navy as an auxiliary to masts and sails; and although it has been continually assuming more and more importance, it is in extremely few vessels only that the use of canvas has been dispensed with. If we may believe what we read in the newspapers, the "Inflexible" herself, with her 2-feet thick armour, her 85-ton guns, and her twin engines of 8,500 horse-power is to be furnished with mast and sails. As she is to carry, however, but 18,000 feet of canras to 11,000 tons of displacement (or less than one-half the proportion of the "Hercules"), it is clear that the sail has become completely subordinated to the steam in this ship, while from the "Devastation" and some similar ships sail has disappeared altogether. I think we may safely say that when the steam power comes to be distributed over a greater number of engines, so that all danger is removed of the ship becoming disabled by a loss of all her enginepower at once, masts and sails will finally disappear from heavilyarmonred ressels. We may believe this the more confidently when we note that Naral Officers themselves, and more especially those who have commanded ironclads, or squadrous of ironclads, now cease to demand the use of Eail-power in sach, ships, and consider that very leavily-armoured ressels should not be allowed in any way to depend upon sail for safety.

With the abandonment of masts and sails in such ressels disappears the necessity of adhering in their construction to the ordinary forms and proportions of ships; and we are now free, as I say, to consider in future what is the best form of battery, citadel, or fortress we can adopt, and what are the best means of sending it to sea under steam. I expect to hare the general concurrence of thoughtful officers in saying that with armour already 2 feet thick in the "Inflexible," and a hull to carry it made larger than any previous ship except the "Great Eastern," it is time that we ceased to armour mere slips, and set about subordinating ship-shapeness and the use of sails to more momentous considerations.

Seren jears ago I wrote and published a work on "Opr Ironclad Ships," in the Introduction to which I said:- "Our clear duty for "some time to come will be to aroid alike false analogies and specula" tive forecasts, and to develop as steadily and as rapidly as heretofore "the power, both of the gun with which we assail the enemy, and of "the armour with which we repel his assaults upon us. As an "encouragement to this course, it may perhaps be not amiss to " mention that I have myself devised plans for carrying extremely "heary armour, which it has not yet been necessary to dirulge, but 
"which will come into active play when we have attained to the use " of such thicknesses of armour as are now deemed too great for eren "a moment's consideration by those who think superfieially upon this "subject."

The basis of that remark was that, I had then foreseen, that as armour increased in thickness and guns in weight, their requirements would more and more overpower the requirements of mere steam and sailing ships, and that ironclad ships would have to be made first and foremost armoured and armed sea citadels. Starting with this idea, and desiring to preserve as many of the qualities of a ship as were consistent with it,' I projected at the Admiralty a number of tentative designs on the general principle exhibited in the annexed diagrnm, Fig. 7, the citadel having sufficient buoyaney and stability to maintain the ressel afloat at her fighting draught, and with the necessary stability, eren when the ends were filled with water as shown By the desire of Lord Dufferin, I explained my views on the subject to the Admiralty Committee of Designs, in April, 1871 ; and, at the request of the Com- mittee, Mr. Barnaby, the present able Director of Naval Construction, was good enough, at a later period, to furnish certain additional observations on the subject. Between ships of this class, and those subsequently adrocated by Admirals Elliot and Ryder, or the "Inflexible" herself, I cannot discern any difference of principle whatever. It has been proposed, I believe, in those cases to place cork, stow coal, \&-c., in the water spaces, but these are details that do not affect the general principle. It must be understood, however, that beyond claiming to have laid down this general principle of the plan I do not go; the "Inflexible's" design in all other respects being solely dne, I believe, to the Construction Staff of the Admiralty.

I have dwelt upon this type of design for a reason which you will now discern. The object in originating it was, as you will see, to build a very strongly armour-plated citadel carrying very heavy guns, and to add as little additional armour as possible to that which the citadel demanded. All the armour I proposed to employ apart from the citadel was, as sou will observe, that of an under-water deck 3 or 4 inches thick, and that deck I sought to make rery short. Still, in time of battle, the water must be let in at the ends, and that water took the place of a belt of armour of about equal weight, and to that extent the citadel was further encumbered.

Two years after the publication of the book above referred to, I went to Russia, and there I found that Admiral Popoff had designed, and the Imperial Government had ordered to be built, iron-plated ressels of circular form for the defence of the Dnieper and of the - Sea of Azof. I saw the keel of the first ressel laid, and during last antumn I had the privilege of inspecting her at Nicholnieff, and of steaming in her from Sevastopol to Theodosia and back to. Yalta. I wrote my impressions of the vessel to The Times, and as the editor has permitted me to republish my letters, what I there said is now accessible to all.

Now the chief characteristic of these circular ironclads is that they are purely and simply sea-citadels, propelled by steam, and without 
any attempt whatever to make them conform to the shape of an ordinary ship.

The question to be determined hereafter is, is this form of vessel, thus originated for const defence purposes, and prored eminently snccessful for that purpose, available under proper modifications, for sea-going citadels.

I think we may fairly sas that for a sen-citadel, viewed as a citadel only, apart from other features, the circular form is best, because it requires a minimum amount of armour to protect a given area or volume; or, in other words, with a giren amount of armour secures the greatest amount of buoyancy. For special purposes some modified form might be preferable, but speaking generally, the circular form is the best for floating armour to protect an included space, and also for giving that equal all-ronnd command with your guns which is so desirable at sea. Starting then with this circular armoured citadel, and wishing to propel it at speed at sca, there are several wass in which we can deal with it.

1. We can put engine-power in it just as it stands, without modif. cation; or,

2. We can build ends to it like those of an ordinary.ship, protecting those ends by a belt of armour, as in the "Bellerophon," "Hercules," and many other ships; or,

3. We can build such ends to it, and protect the lower parts of them by an under-water deck of armour, as in the "Inflexible"; or,

4. We can build around it an outer circle of thin iron, with a mere narrow belt of armour, analagous to the belt of ordinary ironclads; or,

5. We can baild around it such an outer circle of thin iron, witl an under-water deck of armour, analogous to that of the "Inflexible," or

6. We can build short onds to it, with eitleer belts or under-water armour decks, but of greatly reduced length as compared with the ends of ordinary ships of large beam.

The "Norgorod" is the only actual example of the first of these cases that has yet been tried, and we may state roughly that in her, 750 tons of armour, and 56 tons of guns, are carricd on a displacement of 2,500 tons, and driren at about $8 \frac{1}{2}$ knots with 2,270 indicated horse. power. This confirms what we already knew, viz., that such slips will require great power in proportion to displacement. But taking not the false standard of displacement, but the better (althongh not perfect) standard of weight of armour and guns as our guide, we shall find nothing rers extraorlinary in the power required. In the "Warrior," our first ironclad, the armour and the guus protented by it weighed 1,100 tons, and 5,470 indicated horse-power was required to propel it. Ini our next ironclad, the "Defence," the armour and protected guns weighed abont 700 tons, and the indicated horse-power emplojed at full speed was 2,500. Grouping these figures wo have- 


\begin{tabular}{|c|c|c|c|}
\hline & "Norgorod." & "Warrior." & "Defence." \\
\hline $\begin{array}{l}\text { Weight of armour and of guns protected } \\
\text { Indicnted horse power at full speel } \\
\text { l'roportion of powser to weight driven .. }\end{array}$ & $\begin{array}{l}806 \text { tons } \\
2,270 \\
2 \cdot 8 \text { to I }\end{array}$ & $\begin{array}{l}1,100 \text { tons } \\
5,470 \\
4 \cdot 9 \text { to } 1\end{array}$ & $\begin{array}{l}700 \text { tons } \\
2,500 \\
3 \cdot 5 \text { to } 1\end{array}$ \\
\hline
\end{tabular}

It will of course be said that the "Warrior" was driven at 14 knots, and the "Defence" at nearly 12, "while tho "Norgorod's" specd was only 81. But on the other hand, not only was the steam power required in the "Warrior" so much greater as wo sec, but even with this power an enormonsly long aud costly ressel was constructed solely with the object of promotiug speed; and when speed was by these means attained, we still had a ship with only about one-half of her protected, with exposed steering apparatus, and with other very serious defects as a fighting engine. In the "Defence" analogous sacrifices were made, but on a length proportioned; of course, to the reduced speed.

If we take a fully armoured ship, say the "Prince Consort," for comparison, we shall hare the following figures-

\begin{tabular}{lc|c|c}
\hline & "Norgorod." & "Prince Consort." . \\
\hline Weight of armour and guns protected &.. & 806 tons & 1,050 tons. \\
Indicatel horse-power at full specd.. &.. & 2,270 & 4,231 \\
Proportion of power to meight arircn &.$\cdot$ & 2.8 to 1 & 3.9 to 1 \\
\hline
\end{tabular}

Here tho ressel was fully armoured, but the armour was thin, and could be extended orer the whole length of a hull of pretty bluff form of moderate lenerth. But as armour progressed in thickness, to extend it over the whole length would hare been to increase greatls the size, power, and cost of the ship, and therefore we were obliged to resort to central batteries or citadels, the water-line armour alone extending from stem to stern. This of conrse involved a still greater proportion of power to weight of citadel and guus, although it cnabled us to keep down the size, power, and cost.

Wre may start, therefore, by saying that the circular ironclads havo started with a macl less proportion of steam power to citadel armoar and guns than has asually been given to ironclads, and not with an cuormously greater power as many, persons have been too rendy to suppose; and I must say that before resorting to the adoption of enormons ends, whether armoured or unarmoured, as a means of fining the lines, it is incumbent upon us to investigate low far it is possible, or wtherwise, to get ligh speed by merely incrensing the power. As comp:ered with ordinarg forms the power required to drive at high speed a circular ship of cqual displacement, will probibly be from two to three times that required for an equal displacement obtained on ordinary lines, or eren more; bat then displacement, as wo hare scen, is no sufficient basis, and the problem is to find out the true basis, and to proceed upon that.

I feel persuaded that the circular ship or citadel will lereafter be vui.. $\mathrm{xx.}$ 
taken at least as the point of departure, if I may so speak, of our investigations. It is idle to say, as has been said, that it is impossible to pat engine-power enough in it to drive it at high speed, because the engine-carrying and coal-carrying power can be enormously increased, while preserving the circular form by the plans suggested in cases 4 and 5 before given. We are just as free to extend our unarmonrer hull, or our belt-protected hull, or our under-water-deck-protected hull all round a circular armoured citadel, as we have been to extend our rectangular eitadel ships to great length by means of long fine ends protected either as in the "Hercules " or in the "Inflexible;" and $I$ can see many advantages in doing so.

But there is one consideration which strongly tends, in my opinion, to farour the adoption of a short bow and stern in these vessels of extreme breadth, and that is, that the power of the vessel to steam against a head-sea would thereby be improved. This opinion is in some small degree based upon my observations in the "Novgorod," but as her speed is so small, no marked features were in this respect developed. But there are considerations, based upon the relations between wave-periods and a ship's period of longitudinal oscillation, and of the changes in these relations effected by great speed, which point strougly to the value of some elongation of the form especially at the bow in order to facilitate steaming ugainst a head sea at speed. I have had the advantage of a conversation on this subject with that very eminent investigator of naval science, Mr. Froude, and I think I may venture to say that he fully concurs with this riew, and attaches to it even more importance than I at first did. The accompanjing diagram, Plate III, fig. 8 , shows that, with a comparatively small increase of armour, the circle may be developed into an approximately ship-shape form of short length and great breadth.

But knowing as I do much of the mind of Admiral Popoff on this matter, I think I may safely say that he is quite as ready as fou or I would be to make any modifications of the circular form which either high speed or any other special object may require. He has, as I hare intimated, added eren to his coast defence vessels a protrusion from the strict circular form at the stern to assist in housing the rudderhead; and for sea-going ships, he has before now suggested the prolongation of the bow into a ram. He bas taken so much pains to assert and reiterate that his great object is to promote economy and efficiency by extreme shortening and brondening of ships, and has achioved, as I believe, so distinguished a success, that although he has taken the circular form as his emblen and battle-flar, so to speak, his great object would be accomplished and his victory won-and mine with his-if the present proportions of heavily-armoured ships were superseded, even though the circular form were stretched to an oval, or made pointed at the bow and stern, or even modelled into something like a ship-shape, provided only that the full benefit of extreme breadth and shortness are secured. It would be presumptuous in me, at the present stage of the inquiry, to assign perfection and finality either to the trae circle, or to any one particular modification of purely circular lines. I repeat now, what I said before in The Times, 
that I believe the circular form is itself quite compatible with high speed, and certainly it possesses very great and numeroús advantages in other respects. I do not, however, refuse to bring it under the closest scientific scrutiny; I do not say that some modifications of it may not be beneficial; what I suggest is, that you, and especially those of you who influence the Admiralty, should secure for the whole subject impartial and exhaustive investigation. I am glad to say the Idmiralty are haring it investigated; on their behalf MIr. Froude is applying his splendid apparatus and his remarkable faculties to the resistance part of the question. But inquiry must not stop there; Mr. Froude himself, and the Construction Staff of the Admiralty, are well qualified to pursue it much further than that, aud I hope they will pursue it to the end. I have myself thought the matter out sufficiently to bo quite sure that many unexpected advantages will be found to gather arond the principle of making even fast sea-going ironclads extremely broad and extremely short.

The Cirsmusin: We hare now had a full deseription of these ressels, and we find them faroured, if not backed, by the opinion of $\mathrm{Mr}$. Reed, the originator and constructor of that ironclad lleet, of which we are justly proud. Therefore, if any officer or gentleman has anything to say on this subject, I hope he will be good enough to farour us with his obserrations.

Mr. Scotr Resseli : Mr. Chairman and Gentlemen,-As no one else rises, perhaps I may be permitted to offer an obserration or two. It so happens that I was one of the designers of the "Warrior," that I had something to do with the "Great Eastern," and had also to build one of the first so-ealled ironclad batteries; therefore I may be said to hare even a little personal interest in this matter. But I come here to-day merely with the feeling that we are rery much obliged to $\mathrm{JIr}$. Reed for having brought this subject so clearly and so thoroughls before us, and for haring added his own obserrations and opinions to those of the inrentors of this circular sjstem. MIr. Elder is the gentleman who first dereloped the great ralue of circular ressels for steam purposes. He was an old friend of mine, and I was very much struck by the great originality of the system, and by the great wisdom with which Ifr. Elder nerer thought of making it a substitute for ship-shape ships; but merely brought it forward as an instrument for accomplishing certain peculiar ends for which it happened to be peculiarly adapted. For example, he meant it to be, not a substitute for eca-going ships, but to be applied to the purposes of a ferry-boat be. tween Lirerpool and Birkenhead; and he showed me that as a ferry-boat he could by this means carry far more in proportion to its mass of weight and giren draught of water than by any other form, and also that it could be propelled at slow relc. vities mith moderate power. Let me say one word on that subject, in order to be rid of it once for all. At slow velocities allow me to assure you this circular form is propelled nearly as easily as uny other ordinary form, and thercfore let us draw a clear distinction between talking of lur relocities, like 6 or 7 miles an hour, and high relocities, such as we think necessary for our steasn nary-namely, 14 knots an hour. Tliere is no resemblance between them; and this is an admirable shape for one of the purposes, and is totally out of question for the other. With regard to the merits of Admiral Popoff in this matter, allow me to eay that I esteen it quite as highly, if not higher, than that of Mr. Elder. Though Mr. Elder mas hare adopted the circular form, we are indebted to ddmiral Popoff for having adopted this circular form and propelled it for the special purpose of naral warfare. Admiral Popoff four or six years ago was bind enough to explain to me all his riews on that subject. I entirely coincided with those riews, and I think this ressel a rery admirable thing, so long as you do not call it a ship. Now this floating battery-for it deserres the name- of a circular form is nost admirably adapted for carrging the heariest armaments and the heariest armour, and for the special purpose of local defence, for which it ras designed. Admiral Popoff is entitled not only to our thanks, but 
io our admiration. Permit me to sas here confidentially that it so happened that I serred professionally on sereral of the Commissions for Const Defence. I had the pleasure of sitting there with some of the most distinguished Admira!s and Generals whom I see here, and we discussed among other things the whole question of fired fortresses, of floating fortrcsics, of eclf-moving fortresses, of elongated fortresses, and of cireular fortresses, and we arrired at a great many conclusions which I dare not tell you here. The question which Admiral Popoff's invention raises is this- "What are the particular places in England "where you think that floating battcries are wanted as coast defences?" Ind if sou know of such places, allow me to say that his experiments show that jou can make excellent ressels for local defence most economically and most conreniently of the circular form. There is another question which he raises : whether it is more expedient to propel these ressels by power within themselres, or to anchor them where they are wanted, or to shift them by tug ressels from the outside? You will find if you onl 5 settle the circumstanees in which you want these defences, the circumstances.will settle for jou which plan is the best. In the one place you will find the fised circular battery is the best; in another, the anchored circular battery is the best; and in another you will find that ressels conreniently mored by other ressels towing them are the best; and, finally, you will find that there are other circumstances in which it is most desirable, at great sacrifice of cost, of machinery, of complication of construction, and so on, to have steam engines to enable you to trusport then from the place where they are stored to the place where they are required.

I come next to the question whether, according to a suggestion made in the paper, fou ought to consider the sea-going qualities of a ship of war as qualities of the sccond or third rank, and whether you should place the armour or the other points in the ship in the foreground, and leare her seaworthy ship-shapeness as a secondary point. On that $I$ will endearour to say all $I$ think in two or three sentences. In the first place, I call your attention to the fact that in all those qualities and quantities quoted by Mr. Reed with reference to this subject he has left out of sight the real question of a sea-going ship $\rightarrow$ ramely, how long a rojoge has it got to make, how much coal has it got to take for that length of royage, and at what rate is it to steam on that royage? Fow those, allow me to tell you, as sea-going qualities and quantities are elements which, I trust, will rulo our future naries, and not the question liow the utmost performance can be got out of a short ship of this or that slape. I think it is most unwise to set up any theoretical notions of what the best possible shape is, and it is most necessary that for erery ship, when it is about to be constructed, you should take into consideration the practical purposes for which that particular ship is wanted. If you do that, you mar get a good ship, and if jou are only to hare a grand ship in general, without any particular duty, you will get a bad ship. If you settle what the speed of rour ship is to be, that will gire sou the length of the ship-the winimum length. If you settle, secondly, what the depth of water is into which she must go, that settles for you the draught of water of your ship. If you then ask me what settles the breadth, I nnswer the weights to be carried and the sea-going qualities settle the breadth? You then say, "Having scttled the mininum length, "what increases the length?" I answer jou in a moment, what increases the length is the length of the royage of the ship. A small quantity of coal in a giren ship will certainly let that ship go at a given speed; but it will not maintain the speed, and will not make the royage. The ship grows in length according to the Iength of the royage she has to mike; therefore, I say, lay down the conditions of your shipfirst of all, then make it a principle that above all things she shall be a seaworthy, sca-going ship. Thirdly, make it a condition that she shall hare the power of remaining long at sea, and that implies her carrying large stores; and if you will then add the particular nature of the serrice she has to perform, you will find all the rest will settle itself. The last obserration I hare to male is an obscrration practically upon my old pet the "Warrior," and practically on this diagram, which Mr. Reed has given you, of a vessel with a central fortress. You all bnow the "Warrior" was the first ressel of this class. I think you all rather liked the "Warrior," as a sca-going, sca-worthy ship. I think also jou all remember that the "Warrior" lad the principle of a central battery, and that that principle of a central battery lıas been followed, and must be followed. Allow me, howerer, to differ entirely from 
3r. Reed on a point he has put forward-namely, that you cannot, without this enomous deck which he has giren, and this mode which he has giren of flling the fore and aft part of the ship with water, make that a good, seaworthy ship. Allow we to say that you can; that there are ample means with a central fortress of haring sour slip beautifully shaped, perfectly like a seaworthy ship, and with all the gunlities you require of speed, stability, and endurance, without making an ugly shape of that kind. If you rill permit me to entreat you, it is not to gire up your old sea-going prejudices of haring a handsome, ship-shape, seaworthy ship. And if you vill take my word for it, neither ugly ships, nor ugly proportions, nor any of these things jou have latel been used to, which hare offended the cye, and hare dis. gusted so inany sailors with their profession,-I say, if you will only get rid of such prejudices as these ars, son will find that jou may to-das hare a perfect central fort, hare an unsinkable ship, hare the best guns and most powerful armour, hare a conrenient, comfortable, and wholesome dwelling, and still have all the benutiful form and sea-going qualities which you had before. Only you must first trill.it, and then jou must gire those people to whom jou confide its construction full poueer to carry out your purpose in the design and in the execution of the work.

Mr. Williay Surrif, C.E.: I wish to correct an error which Mr. Reed seems to hare fallen into. He speaks of this circular shape as being merely a suggestion of the late Mr. John Elder's. Now I think the transactions of this Institution will carry you back to a period when MIr. Elder read a paper here upon the subject of eircular ironclads and other ressels, and you will find he referred not simply to the forry-hoats, to which Jir. Scott Russell has alluded, but also to circular turret-ships and flosting fortifications, of which he gare a rariety of diagrams.' There is one point also to which Mr. Reed has given considerable prominenco: he says the suggestion of Mr. Elder was, that the mid-ship section of the ressel should in erery ense be the are of a circle. That is a rery great error; and you hare only to refer to the Transactions of this Institution, published some jears ago, to find that it is so. In fict, if I look at the diagrams Mr. Reed has placed upon the wall, I see there is little or no difference between them and those which MIr. Elder brought before this Institution. I think it was in 1860 or 1861, during the time the British Association Committee on steam-ship performance were sitting, Mr. Henry Wright, now Secretary to His Grace the Duke of Sutherland, was then preparing a collection of facts and materials sent in from time to time to be recorded in the procediugs of the dssociation; and at that time Mr. Elder described to Mr. Reed, in my presence, the idea he had in his mind, and I adrised him to make a series of experiments, to nscertain the difference of resistance of that particular. form which he deseribed. He had a scries of models made and experimented with thein, and the results were recorded. I think he called upon XIr. Recd, who was not then the Chief Constructor of the Nary, and described his inrention to him, accompanying his description by diagrams. Ind I am sorrs to say that Mrr. Reed did not at that time so fully appreciate the merits and adrantages of the form of ressel them described to him by Mr. Elder as he has since had oceasion to do. Uuder these circumstances, I think it hardly fair to gire Admiral Popoff the full credit for this circular design; and that this occasion ought not to pass without my putting on record that Ifr. Elder certainly mas the first designer of these circular ironclads, not with their mid-stip section, a portion of a sphere, but according to dingrams exactly identical with those which ne see before us.

- IIajor-General Sir Jonx ADYE: Although this question is a naral rather than a military one, still I hope you vill allow me as an artilleryman to make a few rewarks, not upon the general construction of these circular ironelads, but upon the arrangements which hare been made for mounting and fighting theirguns. According to the description which JIr. Reed has giren us, the circular ironclad has in the centre an open-topped fixed turret, that is, an iron martello tower on a loating platform, capable of moring at slow speed. The guns are en barbetle, with a slight command orer the water. Now we all know that the barbette principle affords great lateral range; but tho disadrantages are, that it leares the guns and their detachments fully exposed. These circular ironclads, therefore, if attacked from more points thin one at the same time, offer no defence at all to lateral fire. And there is another danger of mounting guns in this yray so close to the vater, namels, 
that they are liable to be commanded, and the guns and men therefore exposed to great danger. On shore we rarely, if ever, contemplate mounting guns en $b a r$. betie near the level of the water, where serious and close action is expected. We rather seek for a high and a somewhat distant position, where the adrantages of an all-round, lateral, and plunging fire are arailable, ant where the exposure of the men and the guns is reduced to a minimum. Thoso are the principles upon which we construct barlette batteries on shore, and they do not appear to me to be carried out in the present instance. I am quite aware the reply will be, that you maj get greate: speed, and you may get the disadrantages of barbette remedied by the disappearing principle. It is true; but in the circular ships which hare'as jet been built that principle has not been adopted; therefore, I presume that the distinguished Officer who designed them did not find his way to mounting guns except en barbette. Eren if that system were established, you woukd still have an open-topped turret, and therefore, in my opinion, the guns as now mounted, and their detachments, being fully exposed to flank and plunging fire, are not well adapted for close and serious action.

Commander IV. Dawsox, R.N. : In a naral discussion upon circular ressels it does seem rery extraordinary that, surrounded as we are by a great number of most experienced naral Oficers, the whole discussion of such a nautical subject should be left in the hands of military men and of ciril engineers. A great deal that I should hare myself said has been anticipated by Mr. Scott Russell, and by what has just fallen from Sir John Adre. We are incited to consider the use of this ressel, not in its local and limitel application, but as a sea-keeping sbip. One point to which $I$ wish to dmo attention as to its sca-keeping qualities is this, that if the ignorant prejudices of naral Oflicers against a norel construction of this kind are to be met, it must be giren a special name, and not be called is "ship." The rery first requirement of a ship in a sailor's estimation is, that it should constitute is comfortable home, a permanent habitation, in which he can spend his life from. boyhood until he leares the Serrice. It is quite true that in these saucer-shaped diring-bells; or whaterer you choose to call them, air will be pumped in in rerslarge quantities; but I should recommend those who adrocate this ressel as a sea-beeping residence, to ask the manager of the Polytechnic Institution to allow hin to go into the diring-bell there for ten minutes. Ile rould find abundance of air pumped in, and perhaps for that length of time he would not suffer inconrenience; but let him stop there a month, and when he has been in a diring-bell for a month, be would get a rery fair idea of what a life-iong residence in a sea-keeping thing of this kind means. With a rery diminutire amount of light, and with air pumped in at high pressure, he will thus be able to judge of the effect which permanently liring under water will hare upon the spirits as rell as upon the health of the fighting men. If it is desired to reconcile sailors to the adoption of a vessel of this hind for sea-keeping purposes, it must be called by some other name than a "ship." Coming to the point of the special use of such a semi-submerged residence as a ressel of war in the Atlantic: This is a point which involses considerations of fleet manónrres which many naval Oficers present are far more capable of discussing tham $I \mathrm{am}$, and which ought to be discussed from all sides, if vessels of this class are to be opposed or defended in the open sea. It must be remembered that this broad, exposed, and unprotected deck may be met by high-sided ressels of rarious elasses. What would be the relatiro positions of the higl 1 -sided "Sultan's" and "IFercules" and the low and broad-decked ressel when they meet in hostile conflict? In dealing witl such questions, we ought to regard the proposed employment of such a ressel in open water as critics; and therefore $I$ am now looking at this ressel solely from a lostile point of riew, and trying to find out its weak points, putting aside for the moment the many adrantages it may hare in a large area of shallow water like the Sea of Azor, and its possible adrantages eren in the open sea. If a sailor in a high. sided ship had to attack a broad ressel of that kind with an unprotected wide expanse of deck, what would bo the natural tactics that he ought to adopt? Why, he should try to bring his armoured side as close to the exposed low-lying deck ae possible, and to keep his guns depressed as close to that low, wido deck as possible. It might not be safe to lay tho high-sided ship actually alongside, because, I suppose, the enemy would not be so foolish as to trust the defence of his circular 
ressel entirely to guns and armour, but would have torpedoes bristling round the circumference as additional means of defence. But supposing he had such other micans of torpedo defence as would make it dangerous to go alongside, the highsided irouchad should still keep as close as it was safe to gret, and the closer the sided A rers few shells planted through the broad, low decks and bottom of the circular ressel, would sulice to dispose of it. We must remember that that deck presents a rery large and wide target. It presents exactly what a gunner wants, not only for close hriug, but also for distant fring. What a gunner likes to aim at in distant firing is not a targat of great breadth, but a target of great depth-depth being to him akin to leight. An ordinary ship is more easils hit when at an unknown distance, when presented end on to the gunner, than when broadside on, bieause a sliot may, by a mis-judgnent of the distauce, go orer the ship when brondside on, which night possibly lit the decks when she is end on. Therefore, a broad circular vessel would be far inore likely to be hit than a varrow ressel. That a circular ressel would present a much smaller area for the hostile action of torpedoes is evident. But once struck by a proper torpedo cluarge, the adrantago to be derired from cellular construction and water-tight compartments is small. I proper torpedo clarge should make a hole through the bottom large enough for a coach and six to be driren through. I do not think any ressel could float with such a hole in her bottom eren with all the water.tight compartments described, and torpedo charges should be so regulated that the smallest hole they ouglit to make would be one of that size. I do not, therefore, attach rery much ralue to the extri anount of defence against torpedo gained from cellular construction by means of the cireular principle. I find also that the armour of the circular ressel does not extend to the keel, but is the ordinars patch on the side, so that in this respect it is on an equality with high-sided ships. An artilleryman would not aim at that narrow patch, but he would try to aroid it, and there would be large deck surfaces abore and bottom spaces below, which it would be quite possible to gire a good account of. I have not spoken of the unquestionable adrantages of the circular form, nor have I entered into the question from the naral architect's point of view; but, looking at it simpls as a fighting ressel in open water, if I was giren the choice of comnanding either an ordinary high-sided ship with the same armament or this lowdeched circular one, whether $I$ consider the purpose of ramming or the resistance to torpedoes, or artillery purposes, I confess I should prefer the high-sided ship with its superior speed. Whatever adrantage the short circular ressel miglit hare in turning, it would hare this disadrantage, that it could not possibly ram the broadside of any ship unless its own stern was rery nearly at right angles to the side attacked, becalise the breadth of its own bow would in any angular approach keep the spcar from touching the enems, whilst the high-sided enemy aiming at any point whaterer of the periphery miglit run at any part of the circular ressel, and would hare ouly to keep his iron stem in a line with the centre of that satcer, with the certainty of always striking its side at right angles, so that he would most likely thrust his stem right into the heart of the citadel itself. With all its merits, there is a good dial to be said from a tactical point of view against the circular form of ironelad for deep-sea purposes, and I do not know any part of our coast which corrcsponds in expansc of sluallow water to the Sea of Azor. I do not, therefore, see the necessity for ressels of that class being introduced for mere defensire purposes into this country. Eren for the defence of the shallow banks which cover the entrance to the Thames, I would much prefer the same moner's worth of MIr. Rendle's small gunboats to these costly circular ironclads, with rery low freeboard, which offer very large deck targets to the enemg's fire.

Aduiral Sir Spexcer RonIssox, $\boldsymbol{h}$.C.B. : The rery late hour of the afternoon will prerent me troubling you with any but a rery ferr remarks; indeed I should hare risen a little sooner, but I thought there were others better qualified than myself to make rarious remarks on the rery interesting lecture MIr. Reed has giren us. JIs object is simply this, to bring back, if I could, the discussion to the point from which it started. The point JIr. Reed has rery ably illustrated, and has giren us a most interesting lecture upon is, whether for certain well defined purposes a circular ironclad was well designed, or whether it was not? A good many of the gentlemen sho hare spoken hare direrged entirely from that subject. Some hare gone intu 
xsthetic questions, and discussed with considerablo blame, and no approbation whaterer, the ugly ducks that hare been lauuched upon the occan, and that hare done, and will do again, the work the country requires. I mish simply to say we hare had in this lecture of Mr. Reed's a trpe of ship explained to us-no natter from what quarter it comes, whether the origin of this admirable ship for coast defence came from Russia, or came from Glasgow, or camo from England $\rightarrow$ coupled with the fact that we hare had the experience of one himself, a rery eminent Naral architect, who has seen the performance of such a ship at sea, and is able to gire us the whole particulars of her construetion, and of the serrice for which she is likely to be emplojed, and apparently to be a master of the work she has to do. Therefore the question seems to me to be entirely this, is it not worth while for erery person in the Naral profession, and for erergbods who ean influence the opinion of those authorities that gorern the Nary, is it not worth while to consider erery point of this new armoured ressel most carefally, and to see whether it does or does not contain the elements of that rery great success which $\mathrm{Jr}$. Reed has shown it possibly may contain? The question is certainly not as some hare put it, whether a circular ship is in all respects the rery best possible vessel you could put upon the ocean to make long rojages, or to fight jour actions against other ships of different classes; but it is whether this circular ship is not capable of defending places which no other ship could defend, and not only capable of doing so but capable of assaulting places that no other ship could assault? Those are questions that MIr. Reed, without any dogmatism, has put before sou as matters deserring the investigation the Admiralty is prepared to gire it, and $I$ think as matters not deserring the ridicule of any person connected with Naral architecture and Naral arehitects, and certainly not deserring the ridicule of any person who may some day or uther be called upon to fight the battles of this country. Mr. Reed, haring put before us the qualities of this circular ship and its adaptability for certain purposes of offence and defence, tells you that he sees no limit to its application, and that it is possible that liereafter the notorious and self-crident want of speed in these circular ressels might be cured by methods that he has not jet inrestignted, but that he has shown to any reasonable mind are capable of being inrestigated, and so that the problem may be ultimately solved. These are the points, therefore, which I think exery Taral Officer and all the eminent artillerists and engineers here present should tako into consideration:- Hare we or not, a reason to suppose that for certain well defined purposes, men have in the circular ship the means of carrying out our purposes practically and fully? And is it not possible by further inrestigation to find whether the principle is not applicable still further, and whether that point of Naral architecture, that point in all ships which I should be the first to uphold, namely, ercessire speed, whether that cannot be obtained in these forms as well as it can bo obtained in the usual forms of ships? And notwithstanding what we hare heard about their uglincss, notwithstanding that we haro heard that sailors are disgusted with these ships and with recent types of war ships, we may depend upon this, if the principle is a sound one we shall nerer find any sailor objecting to go to sea in a circular ship or eren in a square one if he is required to do so.

II. Wright, Esq.: $d$ s my name has bern mentioned in the course of this discussion, will sou allow me to say that Mr. Flder explained to me that one of the chief features of his resscl was that high epced would be most certainly attained. The diagrams he showed to me years ago before erer the subject was brought before this Institution, agreed, so far as I can recollect, distinctly with these. I know also that he considered the rerolution of the ressel would be one of the most important features in an attack upon an enemy's ressel.

Admiral W. Hodstox STETART, C.B.: I wish to say I had a great deal of conversation with Admiral Popoff as to the circular ironclad, and he gare me to understand he originally designed or intended it to protect certain localities in which he intended to plice obstructions against the adrance of ships. These obstructions owing to the draught of water could not be protected by ironelads or by fixed forts, and therefore could be readily remored by an cnemy if unopposed; and it, was for their protection he designed the circular ironelad. After he had procecded with them te found that they were capable of being mored about with much greater facility, and of giving greater adrantages as to their eca-going qualities, than he had 
originally supposed, therefore the question was opened out to his mind and to many athers in Russia, that this circular form mbich enabled him to carry rery thick grwour with a light draught of water might be used to a much greater extent than he had originally contemplated, which, as I hare said, was to defend obstructed places where lie could not place the usual sort of ironelads, and he could not place forts. Perhaps Mr. Reed will say if that was the idea that ras in Admiral Popoll's mind-

Mr. REED : Quite so.

Admiral Stewire : It may be satisfactory if I mention a report I receired the other diay from the Commander-in-Chicf in China, who commands one of our irondads designed by JIr. Recl. MIr. Reed has touched on a subject that I am sure is often present to the minds of Faral Offeers-the behariour of ironclads in a seawar. Admiral Ryder writes to me from the "Audacious" saying, "Whatever "objections may lave been raised to ships of tho 'Audacious' class, the longer "experience I hare of them the more I am struck with their wonlerful steadiness. "I hare just lately made (he says) a passage running before a hears sea and st rono " rind, all my stern ports barred in, and to our great surprise the ship did not roll " more than ${ }^{\circ}$ to $1^{\circ}$ each was. I half made my mind up to broach her to, to sco wlat "slee would do in such a sea, but the helmsman did it for me. In giving the ship "a yaw he brought her to the wind, and positirely to our great surprise she declined " to take any notice of the sea at all. In ironelad flag-ship of a tiret-class naral "power accompanied me. We were both proceeding before the sume sea. MI "Ulag-ship rolling $2^{2}$ to $1^{\circ}$, the Alag-ship of the other power rolling $20^{\circ}$. I am "happy to say that we are on the most friendly terms: if the conditions were altered "I timk the steads platform mould hare decidedly a great adrantage."

Admiral INGLEYIELD: The words "ugly, unhealthy, and unwholesone" were applied just now to one of our principal ironclads. I have just returned from Ifalta, and I saw the "Derastation" having come into port from a long cruize. She went out with the Hediterranean sjuadron, and returned a month or six weeks after their cruize was orer; and the Captain reported to me she had only two small defects, and those were put to rights in a couple of days. He spoke of the ship as being perfectly seaworthy, wholesome, and comfortable for the men and Oficers, and erergthing he could wish. I think it is my duty to bear this testinony to the qualities of one of our special ironclads of the present day.

Admiral Selwrx: I think the points raised by Mr. Reed in his paper have searcely receired the discussion which he might well bare expected. I hare alwars myself been an adrocato of Mrr. Elder's ideas of marine construction, and I still hold to the same theory as far as it is a theors; but $I$ am disappointed to sec that in secking for a less driught of water Admiral Popoff has thuught it necessary to gire a rery abrupt turn-up to the side of the ship, and I think in this probably is to be found the seeret of the extreme power required to drive that particular circular ship. IIr. Elder's models, although they did preserre a species of spherical form, yet prorided quite sulficient capauity in tonnage to hare carried all the prorisions, stores, guns, avd armour that we could possibly hare nished to put into them; but he also did not ignore the fact that serews were a rers awkward modo of propulsion in such a ressel, and he prorided another form of interual propulsion which I am persuaded will one day take its place rery bigh among the modes of propulsion, if indeed it does not supersede all others, namely, that of the hydruulic propeller, thus obriating the exposed siturtion of the screws, whieh is one of the chief defects of this ressel, and which might probably cause their destruction by the rery sinallest unarmoured ressel that could run against them, Mr. Reed sars that by elongating the ressel better lines can be obtained, and therefore more speed; and those gentlemen who remember what the shape of the centreboard yacht is, or the form of a Chinese junk, would sec what might bo the elongation preserring the spherical outline. I do not exaetly like the form IIr. Reed has shown, and an approach to the centreboard form would gire additional adsantages while it might preserve the sail power. I do not care how much power is put in a ressel, or how much coal if you tell me I must not use it until I go into action, for under such circumstances no Officer or crew can bo properly trained in the use of their ressel. If it be necessary to go to sea and carcfully preserre a rery low rate of speed, and 
to limit the use of the steam till even the engineers get rusty orer their furnaces, I think decidedly sail power should not be ignored. If the centreboard boat with its single sail, or the Chinese junk with its three sails at the outside can obtain rery high apeed, I think there is no carthly reason, if we will consent to abanelon all our traditions about the placing of masts and the description of yards, why we shonld not get sail power in these circular ressels guite suiticient to drire them about the ocean when steam is not allowed or available. But the question of armour carried on these ressels assumes a different complexion the instant the spherical outlines are preserred. It then becomes possible to carry a thickness almost unlimited as well eight fect as eight ibches. I am not one of those who attach any rery large importance to the sawing motion adrocated by Mr. Klder, but I think ramming will hare a great otfensire elfect in that as in erery other ship; and neither am l ove of those who mistake the question as to the surface presented by a circular vessel of this description considered as the area of a target. I think if sou show me a target whose eleration is twenty feet abore the water-line and some six lundred feet long, I shall be more likely to hit that than a circular ressel which esposes no height abore the water-line and only half the length, for she can bo sunk up to the edge of her armour in action, therefore I do not attach much neight to such objections. 'io the question of Artillery en barbette I do attach a certain weight; but il disappears before the fact that dimiral l'opotf has scen that the barbette bisttery is not so applieable as it might be, and that the new ship is expressly designed for carrying disappearing carriag:s. IIs friend, Jlajor Jloncrieff, is in Scotlaud, or I am quite sure he would show you that his principle is particularly applicable to this form of ship. The question of a steady platform has been, since I can remember Artillery questions in this theatre, regarded as of the rers highest importance, and considering that more defence must be giren to our shores in the absence of our leets at sea, it is no answer to say that a comparison mas bo drawn between the sightly sea-going ship and the unsightly sea-going ship in farour of the sightly ship if it be not proposed to put formard for that purpose any such ship. This is derised for a special purposo, and as it has answered begond expectation is it not worth while to consider that prin. ciple as one to be discussed and provided for in our own Naral Estimates, instead of ships which hare been said in the Houscs of Parliament to be entirels unfit to defend the coast on account of their draught of water? I am not one of those who underralue the comforts of a sailor's home, but $I$ am one of those who do not fear to say that there will always be found sailors ready to go to sea in angthing thought to be fit by the powers and authorities that be, for the defence of the nation. I veliere the principle to be good, that it may be successfully dereloped so as to gire ligh speed under steam and great carrjing power whether of guns or armour, and that it is not at all impossible so to derelop and mast it as to combino with those qualities great powers under sail and pructical unsinkability.

Mr. E. J. REED : I am rers much obliged to the Naral Officers who hare spoken in this debate with the single exception of one, and that is $\mathbf{m y}$ friend Captain Dawson, because I do not understand what object any thoughtful Niaral Officer can have in riew in introducing epithets like "diving bell," and phrases of that kind into what ought to be, and what I, to the best of my humble ability, endearoured to make, a simple scientific discussion. I shall not answer Captain Darson because 1 think he lus been answered ulready, and certainly the spirit of his spech has been answered by other Naral Uificers who hare spoten. Nor shall I take rery much pains to reply to my esteemed friend MIr. Scott Russell, because he has an adrantage orer me at all times, which is a rery serious one, and with which $I$ cannot compete, for if not omniscient he knows ererything. And he has done a good cleal too, because I always note in these diseussions it is impossible to speat about the "Warrior" in never so incidental a manner without bringing Jr. Scott Russell to his feet to claim the design of her. Well, 1 lare heard him claim that design a great many times, and I have heard him rery justly claim for the design "great merit," and J. am sure I lave spoken of the "Wurrior" on a thousand occasious with great consideration; but wo are diseussing to-day, Sir, how to send to sea rery thick armour and rery heary guns, and I read in The Times nesspaper a few days ago that the Chief Construct or of Portsmouth Docksard had stated that the " iFarrior" was relegated to harbour serrice, as a ship untit to take her part in the fights of the future of our 
Nary. Therefore I do not understand why we are to be debarred by continual harpings back upon the design of the "Warrior," from discussing the new phrases of the question as they arise. Mr. Scott Russell undertook to tell us all about these circular ships. At first he refused them the name of ships, as did Captain Darson; and $I \mathrm{am}$ sure I refused them the name of ships also. I took rery great pains to moke it clear I was asking this Institution to consider not the construction of ordinary alips, but the construction of engines of war, the primary objects of which were to talie to sca lieary guns protected by thick armour. And that obserration, which 1 earefully abided by throughout $\mathrm{ms}$ paper, answers a great deal that has been said in disparagement. Mr. Scott Russell undertook to tell us all about these circular ressels, but he seems to hare been wrong in what he told us, because he told us they were introduced by $\mathrm{Mr}$. Flder onls for ferry purposes, and he was immediately succeded by a gentleman who told us it was distinctly a mistake, that they were introduced for the kind of purpose we are here considering to-day.

Mr. Scort ResselL: I said thes were supplied by lim to be used for that purpose:

Mr. E. J. REED : I accept the correction, but I found Mr. Scott Russell's remarks went so wide of the rarious interesting points that I hoped they would be confined to, that I am obliged to track him into these rery desultory obserrations which he made. Mr. William Smith remarked that Mr. Elder did design these ressels with fat bottoms. I should be sorry to say he did not. Mr. Smith also stated that Ir. Elder showed me the designs of these ressels. That is certainly most true. It is equally true Sir Samuel Baker showed me lis, but in both casez I hare spoken only from memory, for, as I have said, my object was not to press these riers upon the public, but simply to comply with the request of the Council of the Institution to explain these ressels. I hope that that fact will be borne in mind, because I hare not appeared here to-day for the purpose of thrusting and forcing cireular ships upou anybody's adoption. I concluded my paper, as Sir Spencer Robinson kindly reminded you, by simply saying the subject scemed to me to be so important as to require the careful and close attention of the Admiralty, and I expressed my confdent opinion that the Officers of the Admiralty associated with Mr. Froude were quite capable of working the thing out; and $I$ am quite sure from the rery proper spirit in which Admiral Stewart was good enough to address the mecting you will infer that this subject will receire full consideration.

Admiral STEWAnT : I intended to say, though I omitted to do so, that the question did deserre and should receire the greatest consideration.

Mr. E. J. REED : I am much obliged. I am sure that is all that I desire. I hare no object whaterer in riew except sceing the principle of short lengths and great breadths made arailable to our Nary, in so far as it is consistent with other qualities. I must turn again to Mr. Scott Russell, and distinctly disclaim the strange imputation that he brought against this paper and myself, when he said I had asked you to treat as altogether a secondary thing the seaworthiness of the sort of ressels I was discussing. Why, I took a good deal of pains to explain the grounds upon which I thought such ressels could be made thoroughly seaworthy. I nerer put seaworthiness into any secondary position, becauze I take it for granted that erery man who undertakes to design a ship in which the British sailor is to be sent to sea, will make the seaworthiness and safety of that ship lis first consideration; and I may say more than that; I may say-and I am sure the distinguished offiecr under whom $I$ serred, and who is present, and who has spoken, will bear witness to the fact-that so far as my humble intluence in his ofice rent, it was almass against the adoption of contrirances and schemes for sacrificing the seaworthiness of British ships. Mr. Scott Russél further said, that the speed of a ship at once determines its length, and that is a doetrine $I$ lave heard him propound many times before. (IIr. Scotr Rossell: It is not quite accurate.) Well, perhaps a little in. accuracy will be excused in me as well as in others. I understood Mr. Scott Russell to say, and I hare often thought I heard him sas the same before, that when yon have determined the speed it will gire you the length. (Mfr. Scotr Russels: I added the word "minimum" length.) If I had heard that roord I should hare attached a different value to the obserration. I think from Mr. Scott Russell's point of rier, it is reasonable to suppose that the speed of the ship does determine the minimum 
length. I do not mssclf beliese it does anything of the kind. I beliere, and that is precisely the point I mant brought out in the inrestigation of this subject, that the length has so much to do with the quantity of armour you are obliged to carrs in armoured ressels, that you must not make it the first consideration in determining the dimcnsions and form of your ressel. Ile sars, and he finished with that, that you, gentlemen, can have all you want without departing from handsome forms and thoroughly eca-gning ships. I do not suppose anjone crer doubted that proposition, and I should hardly think a meeting of cultirated gentlemen in the centre of Loudon need to be told that all our plans and discussions are not based upon the assumption that you cannot hare what you wane if you choose to spend unlimited money in obtaining it; but our efforts are alwass directed to get cconomically, cheuply, and in conjunction with a number of other things, what we mant. I think it would be perfect iuadness for the administrators of the Sory to eet up an wsthetic staudurd, which, at the best, changes from das to day; for people who used to imagine erery ironclad the ugliest thing pussible, now consider some of the ironclads as amongst the haudsonest productions of the modern epoch. I distinctly remember the Boird of delniralty, consisting of some of the most emincat naral Otficers of the Serrice, requiring to steam serernl times round the bow of the "A Iercules," becruse they thought it was the handsomest and most appropriato bow for a ship which thes had erer scen. With regard to the origin of these vessels, I do not wish to be understood to hare touched upon tho respectire merits of Jlr. Elder, Sir Samuel Baker, or others in this matter; in fact, I think myself it argues rather $a$ low standard of feeling, when we find continually in discugsions of this kind, when we are dealing with actual results that lare been obtained, people who proposed them in an abstract and thcoretical form spring up and almoet stop the discussions upon the essential merits of the thing, to discuss who had the tirst finger in it. I do not wish to say anjthing too immodest, but I must say 1 attend a good many discussions in which, if 1 thought it prudent and proper, I might say 1 ilad thought beforehand of the norcltics then being propounded, but I do not think that is a subject to engnge our artention in matters of this lind.

Sir Joln Adye made some remarks, which are rery true, with regard to the mounting of guns on the en barbelle system; but I need not point out, because ddmirul Selwyn las stated it, that Admiral Popoif in his eccond ressel abandoned the en barbetle system, which was quite an incident of the first design, and las adopted the disappearing principle in the second, and no doubt he is perfectly free in so far as any liunitations of tho circular form are involred, to adout turrets or any other means of carrying guns that may be desirable. There is nothing in the circular system at all to interfere with that. Adniral Stewart appcaled to we as to the objects with which these ressels were introdinced. A memorandum las been put into my hand to-day by a friend of delmiral Popoff, as a point for me to fall back upon, if necessury. "The idea of circular ironclads was originated in a desire " to strengthen the defences of Ferteh Strait and of the Dnieper Liman; and, "therefore, these ressels were built for the spccial serrice, riz., the action belind " certain obstructions, such a , for instance, a row of fixed torpedoes, \&c., laid " down in the narrowest place of these Straits, so that thesc resscls mas choose the " distance, behind that line, and on approach of the eneny towards that line, they "can retreat, and place th: mselres at such a positiou that the men at the guns " would be safe from the rille fire of the enemy. 'Thus, the open turret and speed of " eight knots of the "Norgorod" do not form ans deficiency whaterer, considering "the real purpose for which that first ship was designed." I fecl sure that, in the minds of the bulk of this meeting, the subject has bece lifted by my paper off the narrow basis in which it would naturally bo placed by mans persons. I riew it ouly from this point of riew. The "Interible" is our latest design. I hope, in referring to her, I shall not be supposed to riew the ship depreciatingly. I think the ressel is a ressel of remurkabls ligh character, which will be found to express the puser of this country in a most admirable manner; but, still speaking quite abstrictedly, and with a riew to the future progress of design, I simpls say we must recognize in such a construction the existence of those lengthened ends. I belicre the circular form, or the circular form with a bow, for sea-going purposes, will be found to gire adrantages ercn orer this tspe, and jou lare heard from the 
reponsible head of the construction branch of the Nary that the subject is reciving his consideration : therefore I do feel I hare not brought an unwortly subcret before you. I will take the liberts of thanking ddmiral Inglefield, as well as Idmiral Stewart, for their kind feeling in choosing this occasion to say a good worl, and a practical mord coming from trustworthy sources, respecting the qualities of certain of IIer MInjesty's ships. You know here well enough how quious a task the construction of those ships is, and you hare also heard to-day gin ready some persons are to cast discredit, contumely, and ridicule upon them. It is a rery satisfactory thing to know, when ships get to sea on service, that those resels give satisfaetion to their Offeers. Here we find a flag-ship in a distant part of the world, and another after perforning a lengthened rogage in the liedi. terrancan, giving a good account of themselres, and it is rery gratifying that, in meetings like this, officers should hare the generosity and spirit to rise and siv met Her Majesty's ships are not what many persons suppose them to be, but are efficient and perform their duts well. I thank you, Sir, and the mecting verr much indeed, for the extremo kindness with which jou hare listened both to my paper and to my remarks in reply.

The Craskirax: I am sure erery one present will join with me in offering a hearty and cordial rote of thanks to MIr. Reed for his rery excellent lecture. 